УДК $631.861+631.821 .1$

DOI 10.36461/NP.2020.54.1.007

\title{
АГРОФИЗИЧЕСКИЕ СВОЙСТВА ЧЕРНОЗЕМА ВЫЩЕЛОЧЕННОГО И УРОЖАЙНОСТЬ СЕЛЬСКОХОЗЯЙСТВЕННЫХ КУЛЬТУР В ЗАВИСИМОСТИ ОТ ПРИМЕНЕНИЯ ПТИЧЬЕГО ПОМЕТА И ИЗВЕСТКОВАНИЯ
}

\author{
Н. П. Чекаев, канд. с.-х. наук, доцент; А. В. Леснов, аспирант \\ Федеральное государственное бюджетное образовательное учреждение высшего \\ образования «Пензенский государственный аграрный университет», Россия, \\ т. 8(8412) 62-83-67, e-mail: chekaev1975@mail.ru
}

\begin{abstract}
В статье показано влияние внесения разных доз куриного помета и известкования на агрофризические свойства чернозема выщелоченного, урожайность яровой пшеницы и гороха. В результате проведенных исследований на опытном поле ФГБОУ ВО Пензенский ГАУ (Пензенская область, Мокшанский район) выявлено, что при внесении разных доз куриного помета и проведения известкования в выщелоченном черноземе наблюдается восстановление утраченной водопрочной структуры, снижение равновесной плотности, накопление и эффективное расходование влаги в течение вегетации. Внесение доз помета от 2,0 до 10,0 т/га повысили урожайность зерна первой культуры (яровой пшеницы) на 22,6-61,1 \%, а применение известняковой муки в качестве химического мелиоранта на фоне применения разных доз куриного помета и в чистом виде на 10,5-77,7 \%. Суммарная продуктивность возделываемых культур за три года исследований в зависимости от доз помета увеличилась на 15,4$42,7 \%$ на фоне без известкования и на 23,8-52,2 \% на известковом фоне, что дало дополнительно от 1,49 до 3,30 т/га зерновых единиц.
\end{abstract}

Ключевые слова: куриный помет, водопрочность почвенных агрегатов, плотность сложения почвы, урожайность.

\section{Введение}

С переходом животноводства и птицеводства на промышленное производство продукции с бесподстилочным содержанием скота и птицы проблема утилизации навоза и помёта, кроме экономической, стала и экологической. Использование в системах удаления экскрементов и помёта гидросмыва привело к негативным экологическим последствиям - загрязнению почв, поверхностных и грунтовых вод [3, 9, 16].

Снижение отрицательного воздействия на окружающую среду, в том числе из-за загрязнения органическими отходами при интенсификации сельскохозяйственного производства, - одна из важнейших задач агропромышленного комплекса [2, 7].

В настоящее время существенно изменились условия содержания и выращивания домашней птицы. Это привело к изменению физико-механических характеристик и химического состава птичьего помёта, в больших количествах скапливающегося вблизи птицеводческих хозяйств [6, 11]. Только от одной птицефабрики средней мощности ежегодно поступает до 40 тыс. т. птичьего помёта. К утилизации такого его количества птицефабрики России оказались неподготовленными. Накапливание помётной массы около производственных зон создаёт реальную опасность загрязнения окружающей среды и приводит к большим потерям ценных удобрительных качеств помёта [13].

Поскольку использование органических отходов производства в качестве удобрений сопряжено с определённой экологической опасностью, следует применять только то их количество, которое не наносит вред агроэкосистеме и окружающей природной среде. Следовательно, необходимо определить максимальное количество отходов, которое можно утилизировать на конкретной площади в некоторый отрезок времени без ущерба для окружающей среды $[4,5,10]$.

Использование комбинированных органических удобрений на основе птичьего помёта позволяет обеспечить минимализацию отходов сельскохозяйственного производства и безотходность технологических процессов, а также гарантировать экологическую чистоту окружающей среды и продовольствия [1, 8, 15, 18].

Спорным остаётся вопрос о дозах применения различных видов куриного помёта, которые, по разным источникам, колеблются от 2,5 до 50 т/га и выше [12-14, 17]. Слабо изучен вопрос о длительности последействия помёта в севообороте, нет 
сведений о степени использования элементов питания из помёта в первый и последующие годы после внесения.

\section{Методы и материалы}

С целью изучения влияния разных доз куриного помета и известкования на агрофизические свойства чернозема выщелоченного и урожайность сельскохозяйственных культур на опытном поле учебнопроизводственного центра ФГБОУ ВО Пензенский ГАУ (Пензенская область, Мокшанский район) заложен полевой опыт по следующей схеме:

Фактор A - дозы куриного помета:

1. Без удобрений;

2. Помет куриный 2 т/га по сухому веществу (2,8 т/га в натуральном весе);

3. Помет куриный 4 т/га по сухому веществу (5,6 т/га в натуральном весе);

4. Помет куриный 6 т/га по сухому веществу (8,4 т/га в натуральном весе);

5. Помет куриный 8 т/га по сухому веществу (11,2 т/га в натуральном весе);

6. Помет куриный 10 т/га по сухому веществу (14,0 т/га в натуральном весе)

Фактор В - известкование:

1. Без известкования (контроль);

2. Известняковая мука (Доза $\mathrm{CaCO}_{3} 1,5 \mathrm{Hr}$ );

Повторность опыта четырехкратная, размещение вариантов методом рендомезированных повторений, учетная площадь одной делянки 17,5 м².

В опытах использовали полуперепревший куриный помет с ОАО Птицесрабрика «Васильевская» (Пензенская область, Бес- соновский район). В качестве подстилки при содержании птицы использовали опилки. Помет характеризовался следующими показателями: азот - 3,0-3,5 \%, фосфрор 3,0-3,3 \%, калий - 2,0-3,0 \% , окиси кальция и магния - 1,6-1,8\%.

Исследования проводились на черноземе выщелоченном среднегумусном среднемощном тяжелосуглинистом. Содержание щелочногидролизуемого азота характеризуется как среднее, подвижного фосфора - среднее, подвижного калия - повышенное, реакция почвенного раствора кислая ( $\left.\mathrm{pH}_{\text {сол }} 4,9\right)$.

РезультатыМногие важнейшие с агрономической точки зрения водно-физические свойства почвы - водопроницаемость, плотность, пористость, влагоемкость и другие - находятся в функциональной связи с агрегатным составом почвы.

Как показали исследования, максимальное количество водопрочных макроагрегатов было отмечено в варианте, где применяли куриный помет в дозе 10 т/га на известковом фоне. Содержание водопрочных агрегатов на этом варианте в 2017 году было 67,1\%, а 2018 году 71,1 \%, что на 16,2 и 19,4 \% выше, чем на контрольном варианте и на 10,4-13,6\% выше, чем на аналогичном варианте без известкования. На контрольном варианте наблюдали незначительное увеличение количества водопрочных агрегатов в 2018 году по сравнению с 2017 годом (табл. 2). В 2019 году содержание водопрочных макроагрегатов

Таблица 1

Влияние разных доз куриного помета и известкования на водопрочность макроагрегатов в черноземе выщелоченном

\begin{tabular}{|c|c|c|c|c|c|}
\hline \multirow[b]{2}{*}{ Вариант опыта } & \multicolumn{5}{|c|}{ Количество водопрочных макроагрегатов, \% } \\
\hline & 2017 г. & 2018 г. & 2019 г. & $\begin{array}{c}\text { В среднем } \\
\text { за три года }\end{array}$ & $\begin{array}{l}\text { Отклонение } \\
\text { от контроля }\end{array}$ \\
\hline \multicolumn{6}{|l|}{ Без известкования } \\
\hline 1. Без удобрений (контроль) & 50,9 & 51,7 & 51,4 & 51,3 & 0,0 \\
\hline 2. Куриный помет 2 т/га & 51,6 & 52,4 & 52,1 & 52,0 & 0,7 \\
\hline 3. Куриный помет 4 т/га & 55,0 & 55,8 & 54,6 & 55,1 & 3,8 \\
\hline 4. Куриный помет 6 т/га & 55,2 & 56,0 & 55,1 & 55,4 & 4,1 \\
\hline 5. Куриный помет 8 т/га & 57,2 & 58,1 & 56,2 & 57,2 & 5,9 \\
\hline 6. Куриный помет 10 т/га & 56,7 & 57,5 & 55,1 & 56,4 & 5,1 \\
\hline \multicolumn{6}{|c|}{ Известкование - доза $\mathrm{CaCO}_{3} 1,5 \mathrm{Hг}$} \\
\hline 1. Без удобрений & 56,1 & 59,5 & 58,6 & 58,1 & 6,8 \\
\hline 2. Куриный помет 2 т/га & 56,6 & 60,0 & 59,1 & 58,6 & 7,3 \\
\hline 3. Куриный помет 4 т/га & 60,8 & 64,5 & 64,1 & 63,1 & 11,8 \\
\hline 4. Куриный помет 6 т/га & 62,4 & 66,1 & 65,9 & 64,8 & 13,5 \\
\hline 5. Куриный помет 8 т/га & 65,2 & 69,1 & 65,2 & 66,5 & 15,2 \\
\hline 6. Куриный помет 10 т/га & 67,1 & 71,1 & 68,9 & 69,0 & 17,7 \\
\hline \multicolumn{6}{|l|}{$\mathrm{HCP}_{05}$} \\
\hline Фактор А & 0,8 & 1,2 & 1,4 & & \\
\hline Фактор В & 2,3 & 3,6 & 2,9 & & \\
\hline Варианты (A + В) & 3,0 & 4,4 & 4,1 & & \\
\hline
\end{tabular}


на вариантах опыта колебалось от 51,4 до $68,9 \%$, хотя наметилась тенденция к снижению их содержания.

Внесение разных доз помета позволило повысить содержание водопрочных агрегатов в первый год действия до 51,6$57,2 \%$, что было выше контрольного варианта на 0,7-6,3\%. Известняковая мука в норме 1,5 Нг значительно повысила содержание водопрочных агрегатов в черноземе выщелоченном. На вариантах с известкованием, в зависимости от доз куриного помета, водопрочность макроагрегатов увеличилась в первый год действия на $5,7-16,2 \%$, а на второй год действия на 8,3-19,4\%.

В среднем за три года исследований содержание водопрочных агрегатов на вариантах с разными дозами куриного помета составило от 51,3 до $56,4 \%$, разница с контрольных вариантом была от 0,7 до $5,9 \%$. На известковом фоне содержание водопрочных агрегатов в среднем за три года увеличилось по сравнению с контролем на 6,8-17,7\%. Увеличение водопрочных агрегатов на вариантах с известкованием связано с изменением состава поглощенных оснований в сторону насыщения обменным кальцием и увеличением органического вещества, внесенного с куриным пометом в почву.

Использование куриного помета и известкования оказывают определенное влияние на величину плотности сложения чернозема выщелоченного (табл. 2).
Так, при внесении куриного помета в дозе 10 т/га равновесная плотность (плотность в конце вегетации) в 2017 году в слое почвы 0-30 см снизилась по сравнению с контрольным вариантом на $0,1 \mathrm{r}^{2} \mathrm{~cm}^{3}$, а

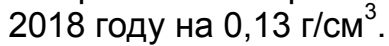

Под действием химического мелиоранта величина равновесной плотности снизилась по сравнению с контрольным вариан-

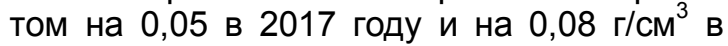
2018 году. Наименьшую плотность в 2017 году наблюдали на вариантах с внесением куриного помета в дозах от 6 до 10 т/га и известкования, плотность при этом соста-

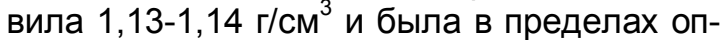
тимальной. В 2018 году, во второй год действия удобрений и извести, плотность почвы была самой низкой на варианте с дозой 10 т/га на фоне известкования.

В 2019 году значения равновесной плотности на вариантах опыта сохранили тенденцию. Наименьшие значения были на вариантах с более высокими дозами куриного помета, особенно на известковом фоне. В среднем за три года исследований равновесная плотность чернозема на вариантах опыта изменялась в пределах от

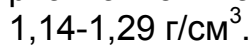

На фоне известкования значения равновесной плотности по вариантам были ниже по сравнению аналогичными дозами куриного помета без известкования.

Влажность почвы при проведении исследований определялась в начале и в конце вегетации возделываемых культур.

Таблица 2

Влияние разных доз куриного помета и известкования на равновесную плотность чернозема выщелоченного

\begin{tabular}{|c|c|c|c|c|c|}
\hline \multirow[b]{2}{*}{ Вариант опыта } & \multicolumn{5}{|c|}{ 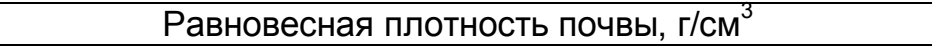 } \\
\hline & 2017 г. & 2018 г. & 2019 г. & $\begin{array}{l}\text { В среднем } \\
\text { за три года }\end{array}$ & $\begin{array}{l}\text { Отклонение } \\
\text { от контроля }\end{array}$ \\
\hline \multicolumn{6}{|l|}{ Без известкования } \\
\hline 1. Без удобрений (контроль) & 1,26 & 1,31 & 1,29 & 1,29 & 0,00 \\
\hline 2. Куриный помет 2 т/га & 1,22 & 1,22 & 1,23 & 1,22 & $-0,07$ \\
\hline 3. Куриный помет 4 т/га & 1,19 & 1,18 & 1,20 & 1,19 & $-0,10$ \\
\hline 4. Куриный помет 6 т/га & 1,17 & 1,16 & 1,19 & 1,17 & $-0,12$ \\
\hline 5. Куриный помет 8 т/га & 1,17 & 1,19 & 1,20 & 1,19 & $-0,10$ \\
\hline 6. Куриный помет 10 т/га & 1,16 & 1,18 & 1,19 & 1,18 & $-0,11$ \\
\hline \multicolumn{6}{|c|}{ Известкование - доза $\mathrm{CaCO}_{3} 1,5 \mathrm{Hг}$} \\
\hline 1. Без удобрений & 1,21 & 1,23 & 1,21 & 1,22 & $-0,07$ \\
\hline 2. Куриный помет 2 т/га & 1,19 & 1,21 & 1,19 & 1,20 & $-0,09$ \\
\hline 3. Куриный помет 4 т/га & 1,16 & 1,19 & 1,19 & 1,18 & $-0,11$ \\
\hline 4. Куриный помет 6 т/га & 1,13 & 1,16 & 1,18 & 1,16 & $-0,13$ \\
\hline 5. Куриный помет 8 т/га & 1,14 & 1,16 & 1,17 & 1,16 & $-0,13$ \\
\hline 6. Куриный помет 10 т/га & 1,13 & 1,13 & 1,15 & 1,14 & $-0,15$ \\
\hline $\mathrm{HCP}_{05}$ & & & & & \\
\hline Фактор A & 0,07 & 0,10 & 0,04 & & \\
\hline Фактор В & 0,03 & 0,06 & 0,09 & & \\
\hline Варианты (A + B) & 0,09 & 0,12 & 0,11 & & \\
\hline
\end{tabular}


Как показали исследования, влажность почвы сразу после посева культур на опытных участках колебалась в пределах от 23,3 до $28,5 \%$. На вариантах с разными дозами помета влажность почвы была выше по сравнению с контролем на 1,8-3,3 \% в 2017 году, на 2,6-4,4 \% в 2018 году и на 2,5-4,3 \% в 2019 году.

В конце вегетации влажность почвы на вариантах опыта зависела от погодных условий и колебалась по годам: 19,7-23,9 \% в 2017 году, 13,5-17,1 \% в 2018 и 17,9-21,2 \% в 2019 годах.

Для агрономической оценки гидрологического режима почв и влагообеспенности растений по показателям их воднофизических свойств проводят расчеты запасов влаги в профиле почв на необходимую мощность (пахотный и корнеобитаемый слои) почвы. Их выражают в кубических метрах на гектар (тоннах на гектар) или в мм водного слоя.

Для сельскохозяйственного производства основное значение имеет только та часть почвенной влаги, которая обеспечивает формирование урожая культурных растений, т. е. превышает влажность устойчивого завядания. Поскольку лишь эта влага используется для фрормирования продуктивности сельскохозяйственных растений, ее называют продуктивной влагой.

Согласно оценочной шкале запасы продуктивной влаги сразу после посева для слоя почвы 0-30 см были хорошие и очень хорошие и колебались от 39,9 до 54,5 мм (табл. 3).

В конце вегетации культур по годам исследований запасы продуктивной влаги резко отличались. Так в 2017 году запасы продуктивной влаги в конце вегетации яро- вой пшеницы характеризовались как неудовлетворительные на варианте без удобрений и удовлетворительные на вариантах с разными дозами помета. В зависимости от доз помета запасы продуктивной влаги увеличились на 6,6-13,0 мм. В засушливый 2018 год запасы продуктивной влаги в почве перед уборкой гороха составили от 2,0 мм на варианте без удобрений до 14,5 мм на варианте с дозой помета 10 т/га. В 2019 году запасы продуктивной влаги оценивались как неудовлетворительные и составляли в пределах 19,0-29,3 мм. Разница по сравнению с вариантом без удобрений составила 3,3-10,3 мм.

Урожайность зерна яровой пшеницы в 2017 году (первый год действия удобрений) на вариантах опыта в зависимости от доз куриного помета и известкового мелиоранта составила в пределах 2,47-4,39 т/га. На вариантах без применения химического мелиоранта урожайность составила от 2,47-4,09 т/га и была самой высокой на варианте с применением дозы помета 8,0 т/га. Отклонения от контрольного варианта достигли 1,62 т/га или 65,5 \% (табл. 4).

Известкование в норме 1,5 Нг повысила урожайность зерна яровой пшеницы в зависимости от доз куриного помета на 0,83-1,92 т/га и была самой высокий на варианте с применением дозы помета 10,0 т/га. Применение мелиоранта без удобрений повысила урожайность зерна на 0,26 т/га.

Урожайность зерна гороха в 2018 году (второй год действия удобрений) в связи с погодными условиями составила в пределах от 1,34 до 1,72 т/га.

Разные дозы куриного помета на второй год последействия увеличивали уро-

Запасы продуктивной влаги в слое 0-30 см

в зависимости от применения куриного помета, мм

Таблица 3

\begin{tabular}{|c|c|c|c|}
\hline \multirow{2}{*}{ Вариант опыта } & \multicolumn{3}{|c|}{ Год исследования } \\
\hline & 2017 г. & 2018 r & 2019 г \\
\hline \multicolumn{4}{|c|}{ Первый срок отбора образцов - после посева } \\
\hline 1. Без удобрений (контроль) & 40,8 & 43,6 & 39,9 \\
\hline 2. Куриный помет 2 т/га & 46,1 & 50,1 & 47,2 \\
\hline 3. Куриный помет 4 т/га & 50,0 & 54,5 & 52,2 \\
\hline 4. Куриный помет 6 т/га & 49,5 & 53,9 & 52,1 \\
\hline 5. Куриный помет 8 т/га & 46,3 & 55,3 & 49,3 \\
\hline 6. Куриный помет 10 т/га & 47,3 & 53,1 & 50,3 \\
\hline \multicolumn{4}{|c|}{ Второй срок отбора образцов - перед уборкой } \\
\hline 1. Без удобрений (контроль) & 25,3 & 2,0 & 19,0 \\
\hline 2. Куриный помет 2 т/га & 37,7 & 7,3 & 25,1 \\
\hline 3. Куриный помет 4 т/га & 37,1 & 10,6 & 22,3 \\
\hline 4. Куриный помет 6 т/га & 31,9 & 9,7 & 26,8 \\
\hline 5. Куриный помет 8 т/га & 38,3 & 9,3 & 27,4 \\
\hline 6. Куриный помет 10 т/га & 36,9 & 14,5 & 29,3 \\
\hline
\end{tabular}


жайность гороха от 0,09 т/га на варианте с внесением 2 т/га помета до 0,34 т/га на варианте с внесением 10 т/га помета.

На известковом фоне разные дозы помета в последействии увеличивали урожайность гороха на 0,23-0,38 т/га. При этом наибольшую урожайность наблюдали на варианте с дозой помета 10 т/га. Разница от последействия разных доз куриного помета в условиях 2018 года была незначительна. Достоверные прибавки получены на вариантах с дозами внесения от 4 до 10 т/га.

Последействие внесенных удобрений в 2019 году испытывали на яровой пшенице. Как показали исследования, урожайность зерна от последействия внесенных доз помета повысилась на 0,28-0,72 т/га. На известковом фоне отклонения от варианта без удобрений составили от 0,12 до 0,88 т/га. Наибольшая урожайность при этом отмечена на вариантах с дозой внесения помета 10 т/га.

Суммарная продуктивность возделываемых культур за три года исследований составила в зависимости от доз помета 7,21-8,92 т/га на фоне без известкования и от 7,74 до 9,55 т/га зерновых единиц на известковом фоне, что дало дополнительно от 1,49 до 3,30 т/га зерновых единиц.

\section{Заключение}

Внесение образующегося куриного помета в ОАО Птицефабрика «Васильевская» (Пензенская область, Бессоновский район) в качестве органических удобрений является не только решением возникающей экологической проблемы, но и дополнительным источником элементов питания для растений в хозяйственном земледелии. Содержание элементов питания в расчете на тонну помета по сухому веществу: азота - 30-35 кг, фросфрора - 30-33 кг, калия - 20-30 кг.

Внесение доз помета от 4 до 10 т/га позволило повысить содержание водопрочных макроагрегатов в среднем за три года действия на 3,8-5,9 \%, а на фоне известкования на 7,3-17,7\%.

С улучшением структурного состояния чернозема выщелоченного под влиянием куриного помета дозами от 4 до 10 т/га и известкования снижается равновесная плотность до оптимальных значений для зерновых и зернобобовых культур.

Внесенные дозы куриного помета от 4 до 10 т/га больше накапливали и меньше теряли влаги в период вегетации по сравнению с вариантом без удобрений. Наибольшие значения запасов продуктивной влаги отмечены на вариантах с дозами внесения помета 8 и 10 т/га.

Применение куриного помета в дозах от 2 до 10 т/га положительно повлияли на урожайность зерна как первой культуры после внесения, так второй и третьей, особенно при внесении доз помета от 6 до 10 т/га. Наибольшая урожайность, в зависимости от применения разных доз куриного помета, наблюдается на фоне известкования.

Таблица 4

Влияние разных доз куриного помета и известкования на урожайность зерна яровой пшеницы и гороха

\begin{tabular}{|c|c|c|c|c|c|}
\hline \multirow[b]{2}{*}{ Вариант опыта } & \multicolumn{5}{|c|}{ Урожайность зерна, т/га } \\
\hline & $\begin{array}{c}2017 \text { г. } \\
\text { яровая } \\
\text { пшеница }\end{array}$ & $\begin{array}{c}2018 \text { г. } \\
\text { горох }\end{array}$ & $\begin{array}{c}2019 \text { г. } \\
\text { яровая } \\
\text { пшеница }\end{array}$ & $\begin{array}{l}\text { Суммарная уро- } \\
\text { жайность за три } \\
\text { года в 3. е., т/га }\end{array}$ & $\begin{array}{c}\text { Отклонение } \\
\text { от контроля } \\
\text { з. е., т/га }\end{array}$ \\
\hline \multicolumn{6}{|l|}{ Без известкования } \\
\hline 1. Без удобрений (контроль) & 2,47 & 1,34 & 2,04 & 6,25 & - \\
\hline 2. Куриный помет 2 т/га & 3,03 & 1,43 & 2,32 & 7,21 & 0,96 \\
\hline 3. Куриный помет 4 т/га & 3,66 & 1,56 & 2,40 & 8,09 & 1,84 \\
\hline 4. Куриный помет 6 т/га & 3,96 & 1,57 & 2,56 & 8,56 & 2,31 \\
\hline 5. Куриный помет 8 т/га & 4,09 & 1,59 & 2,60 & 8,76 & 2,51 \\
\hline 6. Куриный помет 10 т/га & 3,98 & 1,68 & 2,76 & 8,92 & 2,67 \\
\hline \multicolumn{6}{|c|}{ Известкование - доза $\mathrm{CaCO}_{3} 1,5 \mathrm{Hг}$} \\
\hline 1. Без удобрений & 2,73 & 1,40 & 2,16 & 6,71 & 0,46 \\
\hline 2. Куриный помет 2 т/га & 3,30 & 1,57 & 2,40 & 7,74 & 1,49 \\
\hline 3. Куриный помет 4 т/га & 3,99 & 1,64 & 2,48 & 8,60 & 2,35 \\
\hline 4. Куриный помет 6 т/га & 4,18 & 1,67 & 2,64 & 8,99 & 2,74 \\
\hline 5. Куриный помет 8 т/га & 4,09 & 1,69 & 2,76 & 9,05 & 2,80 \\
\hline 6. Куриный помет 10 т/га & 4,39 & 1,72 & 2,92 & 9,55 & 3,30 \\
\hline $\begin{array}{l}\mathrm{HCP}_{05} \\
\text { Фактор A } \\
\text { Фактор В } \\
\text { Варианты }(\mathrm{A}+\mathrm{B})\end{array}$ & $\begin{array}{l}0,27 \\
0,13 \\
0,40\end{array}$ & $\begin{array}{l}0,11 \\
0,06 \\
0,17\end{array}$ & $\begin{array}{l}0,14 \\
0,09 \\
0,23\end{array}$ & & \\
\hline
\end{tabular}




\title{
Лuтература
}

1. Андреева, Н.М.Комбинированные органические удобрения из отходов птицеводства / Н.М.Андреева // Химия в сельском хозяйстве. - 1996. - № 6. - С. 33-34.

2. Бачило, Н. Г. Научные принципы использования помётных удобрений в условиях интенсивного земледелия: диссертация на соискание ученой степени доктора сельскохозяйственных наук / Н. Г. Бачило. - Жодино, 1990. - 452 с.

3. Беззубцев, А. В. Использование птичьего помета в земледелии Омской области / А. В. Беззубцев, А. Г. Шмидт // Достижения науки и техники АПК. - 2013. - № 10. - С. 17-18.

4. Дабахова, Е. В. Агрохимическая характеристика дерново-подзолистых почв после применения птичьего помёта / Е.В.Дабахова, Н. А. Сорокина, В. И. Титова // Агрохимический вестник. - 2003. - № 2. - C. 24-25.

5. Дабахова, Е. В. Разработка методического подхода к определению лимитов на утилизацию органических отходов промышленного птицеводства / Е. В. Дабахова // Бюллетень ВНИИУА имени Д. Н. Прянишникова. - 2003. - № 118. - С. 225-227.

6. Гриценко, В. Л. Экологический мониторинг в зоне деятельности птицеводческих предприятий: автореферат диссертации на соискание ученой степени кандидата биологических наук / В. Л. Гриценко. - Екатеринбург, 2007. - 20 с.

7. Запевалов, М.В.Эфрфективность применения птичьего помета в качестве удобрения / М. В. Запевалов, Ю. М. Наумов // Вестник Челябинского агроинженерного университета. - 2002. T. 37. - C. 118-119.

8. Лысенко, В.П. Из птичьего помёта можно получить высококачественные удобрения / В. П. Лысенко, А. Ю. Семенцов // Земледелие. - 2002. - № 5. - С. 29-30.

9. Отходы птицеводства в качестве удобрений: экологически безопасно и эффрективно / Н. П. Чекаев, А. Ю. Кузнецов, Т. А. Власова [и др.] // XXI век: итоги прошлого и проблемы настоящего плюс. -2015 . - № 5 (27). - С. 130-134.

10. Персикова, Т. Ф. Оценка и прогноз загрязнения поверхностных и подземных вод при использовании куриного помета / Т. Ф. Персикова, Т. Н. Мыслыва, М.В.Царева // Вестник Белорусской государственной сельскохозяйственной академии. - 2018. - № 4. - С. 39-44.

11. Сдобников, С. С. Использование птичьего помёта / С. С. Сдобников, Г.В.Фетисов, Н. П. Гришанов // Химия в сельском хозяйстве. - 1988. - № 12. - С. 21-26.

12. Сорокина, Н. А. Оценка влияния функционирования предприятия промышленного птицеводства на компоненты окружающей природной среды (на примере ОАО Агрофирма «Птицефабрика Сеймовская»): автореферат диссертации на соискание ученой степени кандидата сельскохозяйственных наук / Н. А. Сорокина. - Саранск, 2003. - 19 с.

13. Турчин, В. В. Действие компоста из куриного помета на урожайность и качество семян подсолнечника / В. В. Турчин, А. В. Сисин, Е. Г. Баленко // Вестник Мичуринского государственного аграрного университета. - 2017. - № 4. - С. 14-19.

14. Эфффективность куриного помёта при удобрении сельскохозяйственных культур / С. К. Мингалёв, В. Р. Лаптев, А. В. Абрамчук [и др.] // Аграрная наука. - 2000. - № 8. - С. 17-18.

15. Ягодин, Б. А. Агрохимия: учебник для студентов вузов / Б. А. Ягодин, Ю. П. Жуков, В. И. Кобзоренко; под ред. Б. А. Ягодина. - Москва: Колос, 2002. - 584 с.

16. Defining the optimal dose of chicken droppings for specific production of zooplankton for aquaculture / H. Agadjihouèdé, A. C. Bonou, E. Montchowui, P. Laleye // Cahiers Agricultures. - 2011. - V. 20. - № 4. - P. 247-260. doi: 10.1684/agr.2011.0495.

17. Effect of chicken droppings applied prior to wheat sowing on wheat and paddy rice yields in wheat-paddy rice double cropping system / A. Uchiyama, T. Tanizaki, M. Nakatsukasa, Y. Akasi // Japanese Journal of Crop Science. - 2014. - V. 83. - № 4. - P. 314-319. doi: 10.1626/jcs.83.314.

18. Tagoe, S. O. Effects of carbonized and dried chicken manures on the growth, yield, and $\mathrm{N}$ content of soybean / S. O. Tagoe, T. Horiuchi, T. Matsui // Plant and Soil. - 2008. - V. 306. - № 1-2. P. 211-220. doi: 10.1007/s11104-008-9573-9.

UDC $631.861+631.821 .1$

DOI 10.36461/NP.2020.54.1.007

\section{AGROPHYSICAL PROPERTIES OF LEACHED CHERNOZEM AND YIELD OF AGRICULTURAL CROPS DEPENDING ON THE USAGE OF BIRD DUNG AND LIMING}

\author{
N. P. Chekaev, Candidate of Agricultural Sciences, Assistant-professor; A. V. Lesnov, post-graduate
}

Federal State Budgetary Educational Institution of Higher Education Penza State Agrarian University, Russia, t. 8(8412) 62-83-67, E-mail: chekaev1975@mail.ru

The article shows the effect of introducing different doses of chicken dung and liming on the agrophysical properties of leached chernozem, the yield of spring wheat and peas. 
As a result of studies in the experimental field of the Federal State Budgetary Educational Institution of Higher Education Penza State Agrarian University (Penza region, Mokshan district), it was revealed that when various doses of chicken dung and liming are applied in leached chernozem, the lost waterresistant structure is restored, the equilibrium density is reduced, accumulation and moisture spending are effective during vegetation. Adding doses of the bird dung from 2.0 to $10.0 \mathrm{~T} / \mathrm{ha}$ increased the yield of grain of the first crop (spring wheat) by 22.6-61.1\%, and the use of limestone flour as a chemical ameliorant together with the use of different doses of chicken dung and in pure form by 10.5-77.7 \%. The total productivity of cultivated crops for three years of research, depending on the doses of the bird dung, increased by 15.4-42.7\% on a background without liming and by $23.8-52.2 \%$ on a lime background, which gave an additional 1.49 to 3.30 t/ha of grain units.

Keywords: chicken dung, water stability of soil aggregates, the density of soil consistency, yield.

\section{References:}

1. Andreeva N. M., Combined organic fertilizers made of poultry waste / Andreeva N. M. // Khimiya v selskom hozyajstve. - 1996. - № 6. - p. 33-34.

2. Bachilo N. G., Scientific principles of using dung fertilizers in intensive farming: dissertation for the degree of Doctor of Agricultural Sciences / Bachilo N. G. - Zhodino, 1990. - p. 452.

3. Bezzubtsev V. A., The use of bird dung in farming in the Omsk region / A. V. Bezzubtsev, A. G. Shmidt // Achievements of Science and Technology of AIC. - 2013. - № 10. - p. 17-18.

4. Dabahova E. V., Agrochemical characteristics of soddy podzolic soils after application of bird dung/ Dabahova E. V., Sorokina N. A., Titova V. I. // Agrochemical Herald. - 2003. - № 2. - p. 24-25.

5. Dabahova E. V., Development of a methodological approach to determining limits on utilization of organic waste from industrial poultry farming / Dabahova Dabahova // Bulletin of D. N. Pryanishnikov AllRussian Research Institute of Agricultural chemistry. - 2003. - № . 118. - p. 225-227.

6. Gritsenko V. L., Environmental monitoring in the area of poultry enterprises: abstract of the dissertation for the degree of Candidate of Biological Sciences / Gritsenko V. L. - Yekaterinburg, 2007. - p. 20.

7. Zapevalov M. V., Efficiency of using bird dung as a fertilizer / Zapevalov M. V., Naumov Yu. M., // Bulletin of the State Budgetary Educational Institution of Higher Education «South Ural State Agrarian University». - 2002. - T. 37. - p. 118-119.

8. Lysenko V. P., High-quality fertilizers can be obtained from bird dung / Lysenko V. P., Sementsov A. Yu. // Zemledelie. - 2002. - № 5. - p. 29-30.

9. Poultry waste as fertilizers: environmentally safe and effective / Chekaev N. P., Kuznetsov A. Yu. Vlasova T. A. [et al.] // XXI century: Resumes of the Past and Challenges of the Present plus. - 2015. № 5 (27). - p. 130-134.

10. Persikova T. F., Assessment and forecast of surface and underground water pollution when using chicken dung / Persikova T. F., Mislyva T. N., Tsareva M. V. // Bulletin of the Belarusian State Agricultural Academy. - 2018. - № 4. - p. 39-44.

11. Sdobnikov S. S., Using bird dung / Sdobnikov S. S., Fetisov G. V., Grishanov N. P. // Chemistry in agriculture. - 1988. - № 12. - p. 21-26.

12. Sorokina N. A., Assessment of the impact of the functioning of an industrial poultry enterprise on the components of the natural environment (for example, JSC Agrofirma «Poultry farm Seymovskaya»): abstract of the dissertation for the degree of Candidate of Agricultural Sciences / Sorokina N. A. Saransk, 2003. - p.19.

13. Turchin V. V., The effect of compost from chicken dung on the yield and quality of sunflower seeds / Turchin V. V., Sisin A. V, Balenko E. G. // Bulletin of the Michurinsk State Agrarian University. 2017. - № 4. - p. 14-19.

14. The efficiency of chicken dung in the fertilizing of agricultural crops / Mingalyov S. K., Laptev V. R., Abramchuk A. V. [et al.] // Agricultural Science Euro-North-East. - 2000. - № 8. - p. 17-18.

15. Yagodin B. A., Agrochemistry: textbook for University students / Yagodin B. A., Zhukov Yu. P., Kobzorenko V. I.; eds Yagodin B. A. - Moscow: Kolos, 2002. - p. 584.

16. Defining the optimal dose of chicken droppings for specific production of zooplankton for aquaculture / H. Agadjihouèdé, A. C. Bonou, E. Montchowui, P. Laleye // Cahiers Agricultures. - 2011. - V. 20. - № 4. - P. 247-260. doi: 10.1684/agr.2011.0495.

17. Effect of chicken droppings applied prior to wheat sowing on wheat and paddy rice yields in wheat-paddy rice double cropping system / A. Uchiyama, T. Tanizaki, M. Nakatsukasa, Y. Akasi // Japanese Journal of Crop Science. - 2014. - V. 83. - № 4. - P. 314-319. doi: 10.1626/jcs.83.314.

18. Tagoe, S. O. Effects of carbonized and dried chicken manures on the growth, yield, and $\mathrm{N}$ content of soybean / S. O. Tagoe, T. Horiuchi, T. Matsui // Plant and Soil. - 2008. - V. 306. - № 1-2. - P. 211-220. doi: 10.1007/s11104-008-9573-9. 